Note

\title{
PROTEIN HYDROPHOBIC DRESSING ON SEEDS AIMING AT THE DELAY OF UNDESIRABLE GERMINATION
}

\author{
Odilio Benedito Garrido Assis ${ }^{1 *}$; Ariane Maria Leoni ${ }^{2}$ \\ ${ }^{1}$ Embrapa Instrumentação Agropecuária - R. XV de Novembro, 1452 - C.P. 741 - 13560-970 - São Carlos, SP - \\ Brasil. \\ ${ }^{2}$ Parque Ecológico de São Carlos Dr. Antônio T. Vianna (PESC) - R. São Joaquim, 979 - 13560-300 - São Carlos, \\ SP - Brasil. \\ *Corresponding author <odilio@cnpdia.embrapa.br>
}

\begin{abstract}
Polymer seed-coatings have been largely tested as an alternative method for preventing diseases and have the potential to be used to control undesirable germination and thereby increasing seed storage. Amongst these, the protein-based coatings can be applied with advantage of forming stable biodegradable and hydrophobic films. Due to their chemical structure, protein dressings act as efficient barriers for water uptake, even when seeds are unavoidable exposed to a moist environment. In this work, the effect of hydrophobic dressings was tested on the germination rate of sugar beet (Beta vulgaris L.) and broccolis (Brassica oleraceae var italic L.) seeds under laboratorial condition. Zein, natural maize (Zea mays L.) proteins extracted from gluten meal, was used as precursor polymers to form the coatings. Seeds were dressed by direct submersion into a zein/ethanol formulation of zein concentration of $3.0 \mathrm{~g} \mathrm{~L}^{-1}$, followed by natural air drying. The resultant coating has elevated the hydrophobic feature due to the high content amino acids present in the structure of the zein. For both types of seeds an overall delay in sprouting and germination was observed, with a more accentuated reduction on sugar beet germination percentage after eleven days of measurements. The effect on germination rates is understood as the efficiency of the zein coating to form a physical barrier preventing water permeation into the seeds.
\end{abstract}

Key words: seed dressing, undesirable germination control, protein coating, seed storage

\section{COBERTURA HIDROFÓBICA A BASE DE PROTEÍNAS SOBRE SEMENTES VISANDO A REDUÇÃO DE GERMINAÇÕES INDESEJÁVEIS}

\begin{abstract}
RESUMO: Filmes com características hidrofóbicas baseados em proteínas foram avaliados como revestimento em sementes de beterraba e brócolis, com o objetivo de prevenir germinações prematuras pela redução na absorção de água. Zeínas, proteínas naturais extraídas do glúten de milho, foram empregados como polímeros precursores na elaboração das soluções de cobertura. Os revestimentos se deram pela completa imersão das sementes em formulação zeínas/etanol na concentração de 3,0 g $\mathrm{L}^{-1}$, seguidos de secagem ao ar. Os filmes resultantes apresentam elevada natureza hidrofóbica como resultado do alto teor de amino ácidos presentes na estrutura dessas proteínas. Para ambas as sementes testadas, os resultados apontam um atraso no período de geminação, sendo mais acentuado na porcentagem medida para a beterraba após o período de 11 dias. As diferenças entre as taxas de germinação são discutidas em termos da ação do filme como barreira física reduzindo a permeação de água para o interior das sementes. O estudo demonstra potencial aplicação de zeínas como substrato na redução de germinações indesejáveis durante estocagem em substituição a polímeros usualmente empregados para este fim.

Palavras-chave: revestimento de sementes, controle de germinações indesejáveis, coberturas de proteínas, conservação de sementes.
\end{abstract}

\section{INTRODUCTION}

In a broad sense, seed dormancy can be interpreted as an undesirable characteristic for agricultural cropping since rapid germination and growth are required. However, some degree of dormancy could be advantageous, at least during seed development and storage.

All seed surfaces are basically composed of lignocellulosics like-structures, which present a fast 
degradation by organisms which are capable of breaking them down into digestive units. Additionally, the hydroxyl groups, mainly present in the cellulose chain, are polar groups with high reactivity, suggesting a high affinity towards water (Kiguchi, 1996). Water uptake by itself provokes dormancy break and also accelerated growth (Goodwin, 1966), what can be a problem for long-term storage. Moisture migration within grain containers can lead to detrimental changes in grain appearance and quality and leads to undesirable germination. Storage procedures are normally regulated by monitoring temperature and air moisture (Abdalla \& Roberts, 1969) and alternatively by using polymer coatings to preserve seed features. Coatings provide a physical barrier between the embryo and the environment, delaying undesirable germination and under specific conditions avoiding microorganism infestation (Elzein et al., 2006). Hydrophobic coatings on seeds can be attained either by ion implantation (Volin et al., 2000) or by direct dressing (Chachalis \& Smith, 2001; Willenborg et al., 2004). For both treatments, chemical reactions between cellulose components are expected to take place especially by covalent bonds between functional groups incorporating hydrophobic radicals (English et al., 1994).

In this work zein, a mixture of storage proteins found in the corn endosperm (Wang \& Padua, 2005), is used to form hydrophobic coatings replacing the traditional chlorosilanes or vinyl based-polymers and their performance is studied in relation to the germination rate of sugar beet and broccolis seeds.

\section{MATERIAL AND METHODS}

\section{Zein Extraction and Film Preparation}

The zein used in this work was extracted from the gluten meal (CGM) of the corn cultivar BR473. The CGM is a by-product of starch production in the wet-milling process. This product has up to $70 \%$ of zein, and some polysaccharides are not removed in this process (Wu et al., 1997; Forato et al., 2003). CGM oil extraction was carried out for 24 hours in a soxlhet apparatus with hexane. The residual mass was mixed up with $70 \%$ ethanol for $24 \mathrm{~h}$. Zein was obtained by evaporating the solvent and then lyophilized. For the preparation of film precursor solution, zein was solubilized in $70 \%$ ethanol (30\% water) in concentrations of $3.0 \mathrm{~g} \mathrm{~L}^{-1}$. The solutions were stirred and slightly heated to facilitate homogenization. At this time, polypropylene glycol was gradually added at the ratio of $5.0 \mathrm{wt} \%$ to act as plasticizer.

\section{Seed Coating}

Coatings were obtained by direct immersing of the seeds into the zein/plasticizer solutions for $5 \mathrm{sec}$.
Lots of 25 samples of sugar beet and broccolis seeds were separately dipped into the solution. Excess gel was allowed to drain off and the film was allowed to be formed by drying at room temperature. The use of ethanol as solvent performs the film formation on seed surface by a natural cross chain linkage due to the evaporation of volatile alcohol.

\section{Germination Tests}

To evaluate germination, seeds were placed in plastic boxes (Gerbox) with two layers of filter paper. The paper was previously pressed in a way to form small cavities to uniformily position the seeds which were moistened with $6 \mathrm{~mL}$ of distilled water. The experiments were carried out at $25^{\circ} \mathrm{C}$ for 11 days. A seed was scored as germinated when its radical length as superior to $1.0 \mathrm{~mm}$. Germinating seeds were counted twice a day, starting on the first day and until the eleventh day of imbibition, when on both set of samples the maximum germination percentage was achieved.

Three replicates of 25 seeds were used. For a reference blank test, 25 uncoated seeds of each species also underwent a percentage germination test. The data were submitted to variance analysis, using the square root arc sen transformation and the average values were compared by the Tukey studentized range test $(p<0.05)$. The models which better fitted the points were defined using a mathematical program (Origin 7.03), by using non-linear functions amongst pre-defined curves which resulted in the best $\mathrm{R}^{2}$.

\section{RESULTS AND DISCUSSION}

Differences in median germination time were evident among coated and non-coated seeds. As expected, non-coated seeds presented higher percentage of germination. Zein-coated samples required a longer time for germination.

For the both species the final germination percentages was reduced (Figure 1), with a slight behavior difference between them. The sugar beet coated seeds sprouted almost simultaneously in relation to the non-coated samples. However, the number of germinated coated seeds was inferior along all the evaluated period. After 11 days of measurements, $100 \%$ of the non-coated seeds germinated, against $65 \%$ of coated.

Conversely, for broccolis seeds, the first sprouts have a medium delay of three days in relation to the non-coated seeds, but subsequently the germination follows similar profile, presenting after 11 days $90 \%$ germination compared with $100 \%$ for the noncoated. In general, this behavior differs from tests of hydrophilic dressing on broccolis seeds, which was reported as having no effect on germination rates (Almeida et al., 2005). 

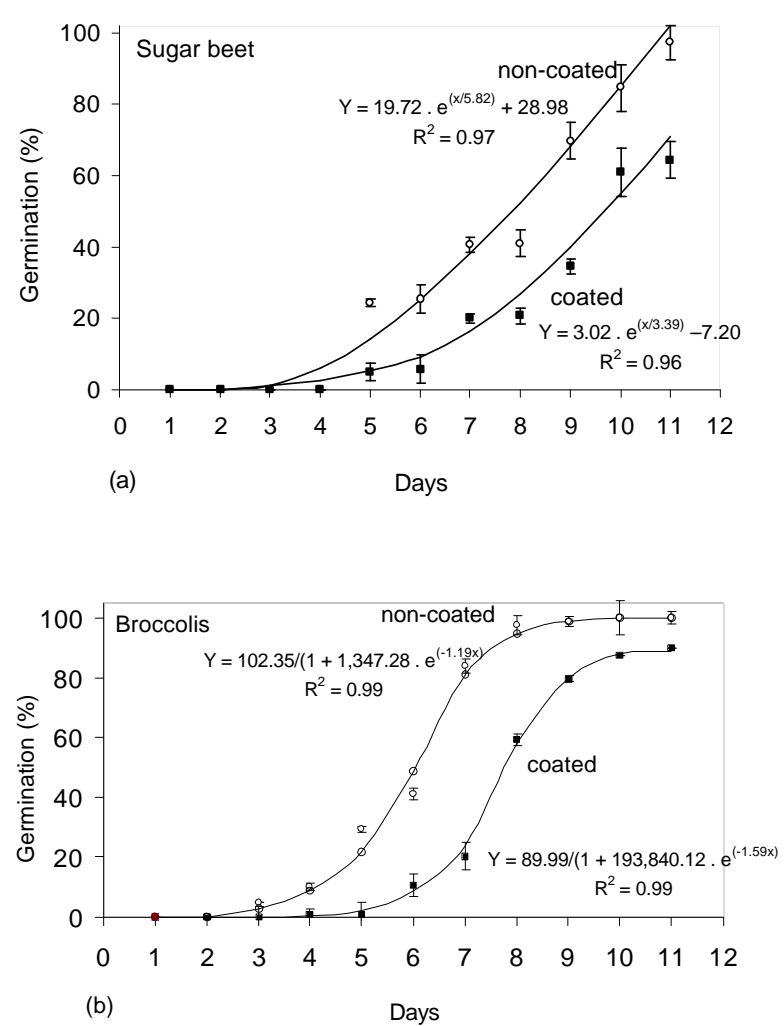

Figure 1 - Percentage germination of zein-coated and non-coated for sugar beet (Beta vulgaris L.) (a) and for broccolis (Brassica oleraceae var italic L) seeds (b). The fitted curves correspond to mathematical models. After the fifth day all data is significant $(p<0.05)$.

The direct comparisons among batches showed quite similar germination rates, no changes being detected for the replicates, which is translated into the small standard deviation (error bar) for each day. The models that best fitted the experimental points were: broccolis $Y=\frac{A_{1}}{1+A_{2} e^{(-t x)}}$, and sugar beet $Y=A_{1} e^{(x / t)}+A_{2}$.

The hydrophobic nature of zein is related to its high content of non-polar amino acids what reduces the water surface interaction. In this sense, the delayed germination can be understood as due to a reduction of osmotic potentials the initial solution. Generally, for good germination rates seeds must have uniform water supply. With the presence of a non-polar interface the water molecules will face difficulties in entering seeds. This situation may actually reduce permeability inhibiting germination, what becomes even more pronounced if the water supply is low.

Uptake of water by a mature dry seed is triphasic, with a rapid initial uptake (phase I) followed by a plateau phase. A further increase in water uptake occurs only after the germination is completed, when the embryonic axes elongate (Debeaujon et al., 2007). The passage of water into the seed during the first phase of germination is quite fundamental (Simon \& Wiebe, 1975). This phase is centripetal so that the outer layers must become more hydrated than the central tissue to promote the bursting of the seed coat. In short, the zein coating reduces the necessary exposure of the seed to water until it obtains sufficient moisture to sprout.

There are some studies on the use of polymer prevention on premature germination through reducing the water uptake by the seed (Watts, 1976; Stewart, 1992). Most of them deal with temperature controlled polymers in which the seeds are prevented from imbibing the water needed for germination until a desired temperature is reached. Most of the used polymers are thermoplastics such as vinyl resin emulsions (Sauve \& Shiel, 1980; Barke \&. Luebke, 1981; Pires et al., 2004) and copolymers of polyvinylacetate (Puglisi \& Guth, 2001), not all of them environmentally friendly or compatible.

Evidently a comparison between these materials and zein should be worthwhile. Anyway, the zein coating showed to be efficient under wet and humid conditions in maintaining a suitable level of seed dormancy, regulating imbibition, which can be strategically applied to reduce premature germination during storage. Additionally, zein is a natural biodegradable, quite amenable polymer to be transformed into coating films, as in conjunction or not with preventive products such as fungicides and insecticides.

\section{ACKNOWLEDGEMENTS}

The authors are grateful to Embrapa and $\mathrm{CNPq}$ for financial support.

\section{REFERENCES}

ABDALLA, F.H.; ROBERTS, E.H. The effect of seed storage conditions on the growth and yield of barley, broad beans, and peas. Annals of Botany, v.33, p.169-184, 1969.

ALMEIDA, C.; ROCHA, S.C.S.; RAZERA, L.F. Polymer coating, germination and vigor of broccoli seeds. Scientia Agricola, v.62, p.221-226, 2005.

BARKE, M.B.; LUEBKE, R.A. Stable protective seed coating. US Patent 4,272,417. 1981.

CHACHALIS, D.; SMITH, M.L. Hydrophobic-polymer application reduces imbibition rate and partially improves germination or emergence of soybean seedlings. Seed Science and Technology, v.29, p.91-98, 2001.

DEBEAUJON, I.; LEPINIEC, L.; POURCEL, L.; ROUTABOUL, J-M. Seed coat development and dormancy. In: BRADFORD, K.; NONOGAKI, H. (Ed.) Seed development, dormancy and germination. Oxford: Blackwell, 2007. p.25-49. (Annual Plant Reviews, 27).

ELZEIN, A.; KROSCHEL, J.; LETH, V. Seed treatment technology: an attractive delivery system for controlling root parasitic weed Striga with mycoherbicide. Biocontrol Science and Technology, v.16, p.3-26, 2006. 
ENGLISH, B.; YOUNGQUIST, J.A.; KRYSIK, A.M. Lignocellulosic composites. In: GILBERT, R.D. (Ed) Cellulosic polymers, blends and composites. New York: Hanser, 1994. p.115-139.

FORATO, L.A.; BICUDO, T.C.; COLNAGO L.A. Conformation of á zeins in solid state by Fourier transform IR. Biopolymers, v.72, p.421-426, 2003 .

GOODWIN, P.B. The effect of water on dormancy in the potato. Potato Research, v.9, p.53-63, 1966.

KIGUCHI, M. Surface modification and activation of wood. In: HON, D.N.S. (Ed) Chemical modification of lignocellulosic materials. New York: Marcel Dekker, 1996. p.197-227.

PIRES, L.L.; BRAGANTINI, C.; COSTA, J.L.S. Armazenamento de sementes de feijão revestidas com polímeros e tratadas com fungicidas. Pesquisa Agropecuária Brasileira, v.39, p.709715,2004

PUGLISI, C.; GUTH, J.J. Seed coating compositions for low temperature applications. US Patent 6,329,319. 2001.

SAUVE, E.M.; SHIEL, R.S. Coating seeds with resins. Journal of Horticultural Science, v.55, p.371-373, 1980.

SIMON, E.W.; WIEBE, H.H. Leakage during imbibition resistance to damage at low temperature and the water content of peas. New Phytology, v.74, p.407-411, 1975.
STEWART, R.F. Temperature sensitive seed germination control. US Patent 5,129,180. 1992.

VOLIN, J.C.; DENES, F.S.; YOUNG, R.A.; PARK, S.M.T. Modification of seed germination performance through cold plasma chemistry technology. Crop Science, v.40, p.1706$1718,2000$.

WANG, Q.; PADUA, G.W. Properties of Zein films coated with drying oils. Journal of Agriculture and Food Chemistry, v.53, p.3444-3448, 2005.

WATTS, H. Method of coating seeds to control germination and the resultant coated seeds. US Patent 3,947,996. 1976

WILlENBORG, C.J.; GULDEN, R.H.; JOHNSON, E.N.; SHIRTLIFFE, S.J. Germination characteristics of polymercoated Canola (Brassica napus L.) seeds subjected to moisture stress at different temperatures. Agronomy Journal, v.96, p.786-791, 2004.

WU, S.; DELAND, J.M.; JOHNSON, L.A. Factors affecting yield and composition of zein extracted from commercial corn gluten meal. Cereal Chemistry, v.74, p.258-263, 1997.

Received March 05, 2007

Accepted June 27, 2008 